University of Nebraska - Lincoln

DigitalCommons@University of Nebraska - Lincoln

Nebraska Game and Parks Commission -- Staff

Research Publications

Nebraska Game and Parks Commission

October 1968

\title{
Effects of Main Stem Impoundments and Channelization upon the Limnology of the Missouri River, Nebraska
}

\author{
Larry A. Morris \\ Nebraska Game and Parks Commission, Lincoln, Nebraska \\ Ralph N. Langemeier \\ Nebraska Department of Health, Lincoln, Nebraska \\ Thomas R. Russell \\ Missouri Department of Conservation, Columbia, Missouri \\ Arthur Witt Jr. \\ Missouri Cooperative Fishery Unit, University of Missouri, Columbia, Missouri
}

Follow this and additional works at: https://digitalcommons.unl.edu/nebgamestaff

Part of the Environmental Sciences Commons

Morris, Larry A.; Langemeier, Ralph N.; Russell, Thomas R.; and Witt, Arthur Jr., "Effects of Main Stem Impoundments and Channelization upon the Limnology of the Missouri River, Nebraska" (1968). Nebraska Game and Parks Commission -- Staff Research Publications. 10.

https://digitalcommons.unl.edu/nebgamestaff/10

This Article is brought to you for free and open access by the Nebraska Game and Parks Commission at DigitalCommons@University of Nebraska - Lincoln. It has been accepted for inclusion in Nebraska Game and Parks Commission -- Staff Research Publications by an authorized administrator of DigitalCommons@University of Nebraska - Lincoln. 
Made in United States of America

Reprinted from Transactions of the American Fisheries Society

Vol. 97, No. 4, 31 October 1968

pp. $380-388$

Effects of Main Stem Impoundments and Channelization upon the Limnology of the Missouri River, Nebraska

Larry A. Morris, Ralph N. Langemeier, Thomas R. Russell and Arthur Witt, Jr. 


\title{
Effects of Main Stem Impoundments and Channelization upon the Limnology of the Missouri River, Nebraska ${ }^{1}$
}

\author{
LARRY A. MorRis \\ Nebraska Game and Parks Commission, Lincoln, Nebraska 68509 \\ Ralph N. Langemeier \\ Nebraska Department of Health, Lincoln, Nebraska 68509 \\ Thomas R. Russell \\ Missouri Department of Conservation, Columbia, Missouri 65201 \\ AND \\ Arthur Witt, JR. \\ Department of Zoology, Missouri Cooperative Fishery Unit, University of Missouri \\ Columbia, Missouri 65201
}

\begin{abstract}
Rigid control has been imposed upon the Missouri River by impounding over one-half of the upper 1500 miles and by channeling most of the remaining river within permanent, narrow banks. These controls have caused environmental changes in the lower Missouri River, as shown by this study, of adjacent unchannelized and channelized sections of river below the main stem impoundments. Impoundments have regulated flow by evening maximum and minimum discharges and improved downstream water quality by decreasing turbidity and indirectly raising the dissolved oxygen. In addition the impoundments have contributed a limnetic cladoceran, Leptodora kindti, to the drift and have affected the distribution of benthos through the modification of turbidity.

Channelization of the river has reduced both the size and variety of aquatic habitat by destroying key productive areas. Average standing crops of benthos were similar in unchannelized and channelized river $(0.63$ and 0.67 pounds per acre, respectively) but the benthic area had been reduced $67 \%$ by channelization. In the channelized river the average standing crop of drift was $8 \mathrm{~g}$ per acre-foot while in the unaltered river the average standing crop was $68 \mathrm{~g}$ per acre-foot. There was little similarity between the organisms of the drift and benthos; however there was similarity between the organisms in the drift and the aufwuchs.
\end{abstract}

\section{INTRODUCTION}

The Missouri River has come under increasing control because of Congressional legislation which provided for the construction of impoundments in the upper Missouri River and on its major tributaries. By July, 1963 , the sixth and last of the main stem impoundments was completed. At full capacity, these reservoirs impound water in over one-half of the upper 1500 miles of river and since the mid 1950's, the downstream flow of water has been under stringent control.

Congressional legislation also called for channel improvements in both the Missouri River and many of its tributaries. Most of the river had been channelized by the time

\footnotetext{
${ }^{1}$ A contribution from Federal Aid in Fish Restoration Project F-4-R, Nebraska, and the Missouri Cooperative Fishery Unit: U. S. Fish and Wildlife Service, Missouri Department of Conservation, Edward K. Love Foundation, and University of Missouri cooperating.
}

the dams were completed. The only unchannelized section below the main stem reservoirs was a 52-mile section immediately downstream from Gavins Point Dam, the lower-most of the main stem dams (Figure 1).

Impoundments have helped regulate the flow of the river by evening maximum and minimum discharges while channelization has stabilized the flow within permanent banks. Control of the river has benefited water transportation interests, encouraged adjacent agricultural and urban development, and provided hydroelectric power.

Although control of the river has resulted in obvious environmental changes, the ecological significance of these changes is largely unmeasured. Neel, Nicholson, and Hirsch (1963) described some of these alterations. They reported water quality was improved after construction of the main stem impoundments and found better environmental con- 
ditions for growth of phytoplankton. Berner (1951) described the limnological characteristics of the channelized lower Missouri River but did not compare these with the limnological characteristics of the unchannelized river upstream.

The intent of this paper is to present limnological information from the unchannelized and channelized river below the main stem impoundments and to compare these findings with those of previous investigations. In this manner it is possible to ascribe certain environmental changes to the main stem impoundments and others to channelization. Further, it is possible to determine which environmental changes are of benefit and which are detrimental to the aquatic community.

\section{PLAN OF STUDY}

Field investigations extended from 1962 through 1964, in that portion of the Missouri River that forms most of the eastern boundary of Nebraska. The upper 52 miles of the study area were unchannelized while the remaining 203 miles were partially or completely channelized.

The objective of channelization was to cause the river to flow in a series of gentle curves utilizing the force of moving water to keep the channel free of silt. The channelized river lacks the numerous chutes and quiet weedy sloughs which were characteristic of the unchannelized river. Brush piles and associated pools were also eliminated by channelization; however, pools were created at the downstream ends of the pile dikes.

Nine sampling stations were established and numbered consecutively downstream from Gavins Point Dam (Figure 1). Stations 1 and 2 were established in the unchannelized river, Stations 3, 4 , and 5 in partially channelized river, and Stations 6, 7, 8, and 9 in completely channelized river sections. Each station was divided into distinct habitats. These were: the main stream; chutes; mud banks; and in the channelized section, barren pools at the downstream ends of pile dikes.

The main stream habitat consisted of the open channel with the swiftest current; depth ranged from 4 to 20 feet, and the bottom was composed of coarse and/or fine sand.

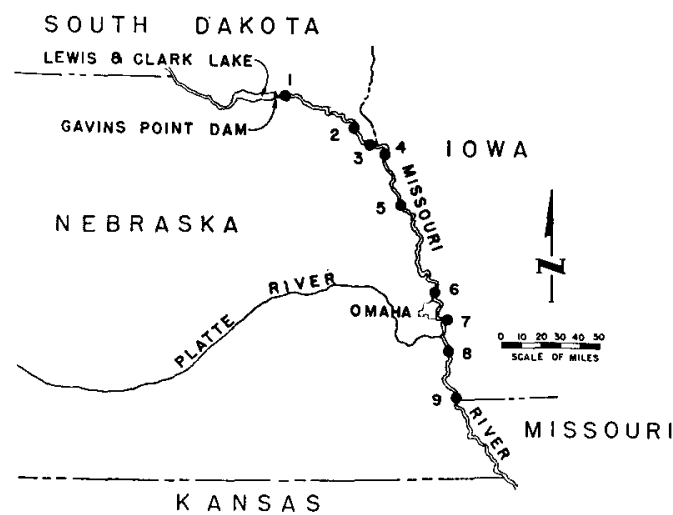

Figure 1.-Location of the sampling stations along the Missouri River, Nebraska.

Chutes were small, quiet side channels which varied in length from a few hundred feet to over one mile. Maximum recorded depth was eight feet, and bottom types varied from sand at the unchannelized stations to silt, frequently heavily laden with organic matter, at the lower channelized stations. In many chutes water levels fluctuated from full flood to complete dryness. In the channelized section chutes were fewer in number, smaller and more temporary than were those of the unchannelized section.

The mud bank habitat consisted of slack water areas with a soft muddy bottom and were located away from the main stream. Water depth ranged from 1 to 12 feet, and the bottom was frequently covered with detritus.

Pile dikes were characteristic of the channelized river and were confined to Stations 3 through 9. Depth in the barren pools created at the downstream end of these structures ranged from 10 to 28 feet. Water moved in a circular direction around the pool's extremities, but there was little current in the center. The bottom was composed of finely packed sand which was occasionally covered with a thin layer of organic matter.

During April through October, 1962, each station was visited nine times. Benthos was collected from each habitat and limnological determinations were made in chutes and in the main stream. During June through August, 1963 , benthos was sampled and limnological determinations were continued at two sites; 
one adjacent to Station 2 and the other at Station 8 , hereafter referred to as $2 \mathrm{~A}$ and $8 \mathrm{~A}$. In addition drift samples were collected at both stations. Lack of a chute at the channelized station precluded sampling this habitat in 1963.

A benthos sample consisted of two hauls with a Peterson dredge from each habitat. A total of 322 two-haul samples were collected during the two-year period. The samples were hand sorted in the field and the organisms preserved in $95 \%$ isopropyl alcohol from 1 to 18 months until identifications and the wet weight determinations were made. Weights were probably minimal because of extended storage (Leonard, 1939; Richardson, 1921).

Drift was sampled with a cone-shaped Brussels nylon net (20 openings per inch) which was suspended 18 inches below the water surface. The net was one foot in diameter with an open area (A) of $0.785 \mathrm{ft}^{2}$. It was placed in the current for 10 minutes (T). During this interval the current velocity (V) was measured with a small Price Current Meter. The cubic feet of water strained (X) during each collection of drift was calculated by use of the formula $X=$ TVA. The amount of water strained per sample varied from about 450 to $2,900 \mathrm{ft}^{3}$. Samples were preserved in 95\% isopropyl alcohol, and debris was separated from the drift by sugar flotation and hand sorting. At the unchannelized station four samples were collected from the main stream and six from the chute; while at the channelized station seven samples were taken from the main stream and six from the downstream side of a pile dike.

During 1964 line transects (24 in the unchannelized river and 16 in the channelized river) were randomly established throughout the study area in order to estimate the amount of aquatic environment and the percentage of each habitat in the unchannelized and channelized river.

\section{CHEMICAL AND PHYSICAL CHARACTERISTICS}

During this three-year study, river dis. charges at Omaha, Nebraska, near the lower end of the study area, ranged from 3,200 to 104,000 cubic feet per second with a mean of 24,263 cubic feet per second (Geological Survey, 1963-65). Usual minimum discharges ranged between 7,000 and 11,000 cubic feet per second during the winter season when water levels were frequently four feet below those of summer levels. Main stream current velocities during 1963 averaged 3.4 $\mathrm{mph}$ at the unchannelized station and 3.5 mph at the channelized station.

Before construction of the main stem impoundments, high turbidity predominated the chemical and physical characteristics of the Missouri River. Ellis (1937) considered turbidity to be the most important factor limiting aquatic life in this river, and Berner (1951) proposed that low dissolved oxygen in the lower Missouri River resulted from oxidation of the organic fraction of the material causing turbidity. Berner reported dissolved oxygen as low as $3.5 \mathrm{ppm}$ and turbidity of 4,500 ppm in early and midsummer with readings as high as $8,000 \mathrm{ppm}$.

Since completion of the main stem dams, flow of the river has been regulated and turbidity has decreased from below Gavins Point Dam all the way to the Mississippi River (Neel et al., 1963). In the present investigation silt turbidity, as measured by the platinum wire, increased at successively lower stations. Measurements ranged from 16 ppm immediately below Gavins Point Dam to over $3,000 \mathrm{ppm}$ in lower portions of the study area (Table 1 ). The turbidity at Station 1 averaged $50 \mathrm{ppm}$ while at Station 8 it averaged $568 \mathrm{ppm}$.

The nearly identical average turbidity in chutes and main stream of the unchannelized river reflected the clarity of water leaving Gavins Point Dam. Further downstream in the channelized river, turbidity in the main stream averaged almost twice that of the quiet chutes.

Improvement in water quality after construction of the main stem dams was also reflected in daytime dissolved oxygen levels (Table 1) which were never below the 5.0 ppm established by Ellis (1937) as necessary for a varied warm-water fish fauna. Lowest concentrations of dissolved oxygen were recorded from downstream stations. In chutes, dissolved oxygen was usually higher than in 
TABLE 1.-Chemical and physical characteristics ${ }^{1}$ of the Missouri River, Nebraska ${ }^{2}$

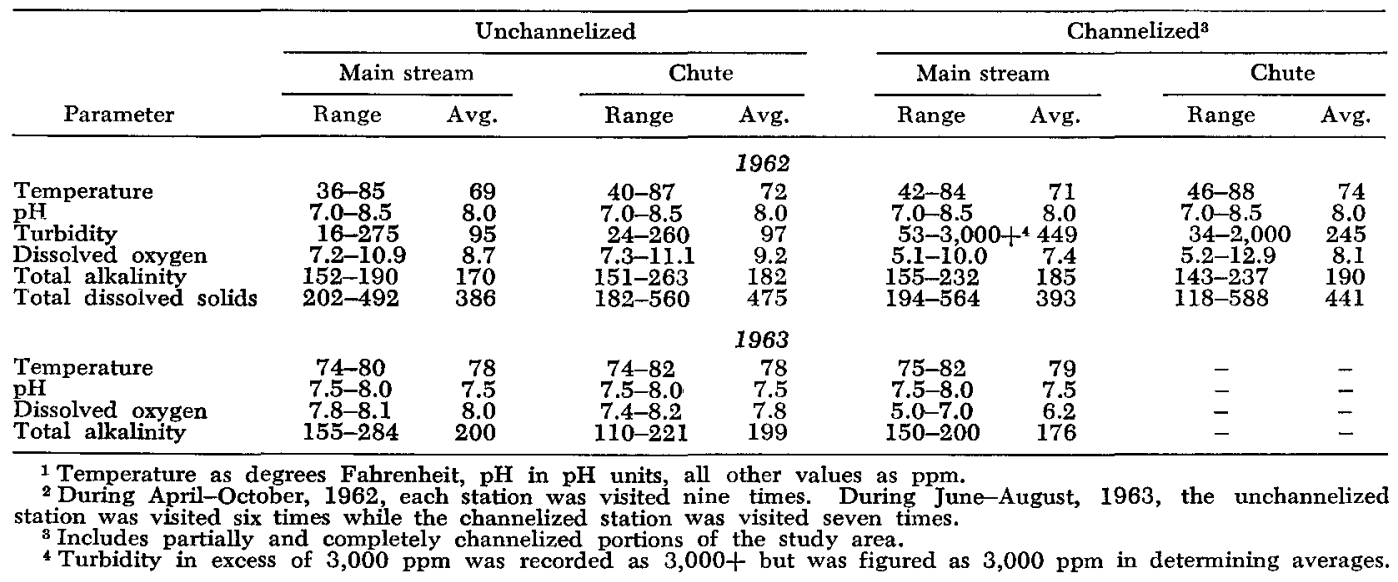

the main stream. Neel et al. (1963) consistently found average dissolved oxygen concentrations to be $85 \%$ or more of saturation below the main stem dams and frequently reported supersaturation for some distance downstream.

Some consistent differences were noted between different habitats. Water temperatures averaged $2.7 \mathrm{~F}$ higher in the chutes than in the main stream and average concentrations of total dissolved solids were greater in the chutes. With the exception of 1963, total alkalinity was greater in the chutes than in the main stream. In 1963 average carbonate alkalinities of $35 \mathrm{ppm}$ were recorded in both chute and main stream habitats of the unchannelized river. Berner (1951) did not detect "normal" carbonate alkalinity from the lower Missouri River, but Neel et al. (1963) reported "normal" carbonate alkalinity ranging up to $10 \mathrm{ppm}$ from the main stem reservoirs to Omaha, Nebraska.

Hydrogen ion concentrations did not differ greatly from those recorded before the flow of the river was regulated (Berner, 1951) or with those recorded afterward (Neel et al., 1963).

\section{BIOLOGICAL CHARACTERISTICS}

Benthos.-In order to determine the longitudinal distribution of the benthos, the identi. fied organisms from all habitats at each station were combined into major taxa (Table 2 ). Oligochaeta were the most abundant orga- nisms (on the basis of percentage composition by weight) at Stations 7 through 9 where they commonly occurred in the deep, silt substrates of chutes and mud banks. They were not nearly so abundant in the same habitats upstream where the water was less turbid and the bottom more sandy. The downstream increase in abundance of the Oligochaeta was probably the result of an increase in turbidity resulting in increased silt deposition on the bottom rather than the result of channelization.

Ephemeroptera and Trichoptera were most abundant at the unchannelized stations. They, like the Oligochaeta, were found in silt, but were most common in chutes and mud bank habitats (usually containing varying amounts of sand) of the relatively clear unchannelized stations. Pennak (1953) commented that Ephemeroptera occur in fresh waters wherever there is an abundance of oxygen. Thus, their preponderance at these stations may have been related to greater amounts of dissolved oxygen immediately downstream from the impoundments.

The relative abundance of Ephemeroptera at Station $7(20 \%)$ is misleading since this represented the weight of only two individuals (Table 2). Station 7 was downstream from the waste outlet of Omaha's meat-packing plants. Here the standing crop of benthos was less than at any other station, and the two mayflies made up a disproportionately large 
TABLE 2.-Relative abundance of benthos in the Missouri River, Nebraska. Values are expressed as percentage composition of the total wet weight for each station. Wet weights $(\mathrm{mg})$ are in parentheses

\begin{tabular}{|c|c|c|c|c|c|c|c|c|c|c|c|}
\hline \multirow{3}{*}{$\begin{array}{l}\text { Taxonomic } \\
\text { group }\end{array}$} & \multicolumn{11}{|c|}{ Stations } \\
\hline & \multicolumn{3}{|c|}{ Unchannelized } & \multicolumn{3}{|c|}{ Partially channelized } & \multicolumn{5}{|c|}{ Channelized } \\
\hline & 1 & $2 \mathrm{~A}^{1}$ & 2 & 3 & 4 & 5 & 6 & 7 & $8 \mathrm{~A}^{1}$ & 8 & 9 \\
\hline Oligochaeta & $20(89)$ & $10(43)$ & $5(23)$ & $5(248)$ & $70(2,193)$ & $26(500)$ & $15(568)$ & $73(112)$ & $58(195)$ & $80(1,293)$ & $89(1,172)$ \\
\hline Insecta & $80(356)$ & $77(324)$ & $95(395)$ & $78(3,964)$ & $26(827)$ & $20(386)$ & $84(3,133)$ & $26(40)$ & $41(141)$ & $20(333)$ & $11(139)$ \\
\hline Diptera & $69(306)$ & $12(50)$ & $23(96)$ & $11(533)$ & $17(525)$ & $15(290)$ & $54(1,990)$ & $4(6)$ & $38(126)$ & $20(322)$ & $9(119)$ \\
\hline Tendipedidae & $68(302)$ & $12(50)$ & $19(79)$ & $10(522)$ & $16(510)$ & $14(267)$ & $51(1,889)$ & $3(5)$ & $36(121)$ & $17(282)$ & $9(112)$ \\
\hline Others & $\mathrm{T}^{2}(4)$ & & $4(17)$ & $T(11)$ & $\mathbf{T}(15)$ & $1(23)$ & $3(101)$ & $T(1)$ & $1(5)$ & $2(40)$ & $\mathrm{T}(7)$ \\
\hline Ephemeroptera & $4(16)$ & $57(239)$ & $57(238)$ & $67(3,362)$ & $8(235)$ & $5(95)$ & $1(45)$ & $19(30)$ & - & - & $2(20)$ \\
\hline Ephemeridae & $4(16)$ & $56(237)$ & $57(237)$ & $67(3,362)$ & $8(235)$ & $5(95)$ & $1(44)$ & $18(28)$ & - & - & $2(20)$ \\
\hline $\begin{array}{l}\text { Hexagenia } \\
\text { Pentagenia }\end{array}$ & $4(16)$ & $\begin{array}{l}46(192) \\
7(30)\end{array}$ & $\begin{array}{l}\mathrm{T}(3) \\
54(225)\end{array}$ & $66(3,303)$ & $8(235)$ & $5(95)$ & T (35) & $18(28)$ & 二 & 二 & $=$ \\
\hline $\begin{array}{l}\text { Pentagenia } \\
\text { Ephoron }\end{array}$ & 二 & $\begin{array}{l}7(30) \\
4(15)\end{array}$ & $\begin{array}{l}54(225) \\
2(9)\end{array}$ & $\underline{1}(59)$ & 二 & 二 & $\underline{T}(9)$ & 二 & 二 & 二 & $\overline{2}(20)$ \\
\hline Baetidae & 二 & $\mathrm{T}(2)$ & $\mathrm{T}(1)$ & 二 & 二 & 二 & $\bar{T}(1)$ & $\overline{1}(2)$ & 二 & $\bar{z}$ & $\underline{2}(20)$ \\
\hline Brachycercus & - & $\mathrm{T}(2)$ & $\mathrm{T}(1)$ & - & - & - & $-\bar{T}(1)$ & - & - & - & - \\
\hline & $-\overline{5}(20)$ & & & & & & T(1) & - & & - & - \\
\hline $\begin{array}{l}\text { Trichoptera } \\
\text { Hydropsychidae }\end{array}$ & $\begin{array}{l}5(2) \\
3(15)\end{array}$ & $\begin{array}{l}88(34) \\
7(31)\end{array}$ & $\begin{array}{r}12(50) \\
9(36)\end{array}$ & $\begin{array}{l}\mathrm{T}(47) \\
\mathrm{T}(4)\end{array}$ & $\begin{array}{l}\mathrm{T}(4) \\
\mathrm{T}(4)\end{array}$ & $\begin{array}{l}\mathrm{T}(1) \\
\mathrm{T}(1)\end{array}$ & $\begin{array}{l}1(38) \\
1(38)\end{array}$ & 二 & $\begin{array}{l}2(7) \\
2(7)\end{array}$ & 二 & 二 \\
\hline Cheumatopsyche & $2(10)$ & $7(30)$ & $6(23)$ & $T(3)$ & $\mathrm{T}(4)$ & & $\mathrm{T}(16)$ & - & $2(7)$ & 二 & 二 \\
\hline Hydropsyche & $1(5)$ & $T(1)$ & $3(13)$ & $\mathbf{T}(1)$ & - & $T(1)$ & $T(22)$ & - & -1. & - & - \\
\hline Phryganeidae & - & $\mathrm{T}(3)$ & - & - & - & 一 & - & 一 & - & - & - \\
\hline $\begin{array}{c}\text { Ptilostomis } \\
\text { Pf }\end{array}$ & - & $\mathrm{T}(3)$ & & $\bar{\pi}$ & - & 一 & - & 一 & - & - & 一 \\
\hline $\begin{array}{l}\text { Psychomyiidae } \\
\text { Polycentropus }\end{array}$ & $2(7)$ & - & $3(14)$ & $T(43)$ & 二 & 一 & - & 二 & - & - & 一 \\
\hline $\begin{array}{l}\text { Polycentropus } \\
\text { Neureclipsis }\end{array}$ & $\overline{2}(7)$ & 二 & $-3(14)$ & $\overline{\mathrm{T}}(43)$ & 二 & $=$ & 二 & $=$ & 二 & 二 & $=$ \\
\hline Odonata & $3(12)$ & $=$ & $3(11)$ & $\mathrm{T}(21)$ & $2(63)$ & 二 & $28(1,052)$ & 二 & $2(8)$ & $\bar{T}(11)$ & 二 \\
\hline Gomphidae & $3(12)$ & - & $3(11)$ & $T(21)$ & $2(63)$ & - & $28(1,048)$ & 一 & $2(8)$ & $\mathrm{T}(11)$ & - \\
\hline Gomphus & $3(12)$ & - & $3(11)$ & $\mathrm{T}(21)$ & $2(63)$ & - & $28(1,048)$ & - & & $\mathrm{T}(11)$ & 一 \\
\hline $\begin{array}{l}\text { Octogomphus } \\
\text { Unidentifiable }\end{array}$ & $=$ & $=$ & $=$ & $=$ & $=$ & $=$ & $\bar{T}(4)$ & 二 & $2(8)$ & $\bar{z}$ & - \\
\hline $\begin{array}{l}\text { Unidentifiable } \\
\text { Hemiptera }\end{array}$ & 二 & $\bar{T}(1)$ & 二 & $\overline{-}$ & 二 & 二 & $\underline{T}(4)$ & 二 & 二 & 二 & 二 \\
\hline Corixidae & - & $\mathrm{T}(1)$ & - & 一 & - & - & - & - & - & - & - \\
\hline Coleoptera & - & - & $\mathrm{T}(\mathrm{T})$ & 二 & 二 & 二 & $\mathrm{T}(8)$ & $3(4)$ & $=$ & $=$ & 二 \\
\hline $\begin{array}{l}\text { Dytiscidae } \\
\text { Hodronbilidoe }\end{array}$ & 二 & $=$ & & - & - & - & $T(5)$ & $3(4)$ & - & - & - \\
\hline $\begin{array}{l}\text { Hydrophilidae } \\
\text { Unidentifiable }\end{array}$ & 二 & 三 & 二 & 三 & $=$ & 二 & $\begin{array}{l}\mathrm{T}(3) \\
\mathrm{T}(\mathrm{T})\end{array}$ & - & 二 & $=$ & $=$ \\
\hline $\begin{array}{c}\text { Crustacea } \\
\text { Isopoda }\end{array}$ & - & - & $=$ & $\begin{array}{l}\mathrm{T}(1) \\
\mathrm{T}(1)\end{array}$ & 二 & 二 & $=$ & $=$ & $=$ & $=$ & 二 \\
\hline Gastropoda & - & - & - & $T(47)$ & - & - & - & $I(2)$ & - & - & - \\
\hline Pelecypoda & - & $13(54)$ & - & $15(728)$ & $3(97)$ & $54(1,032)$ & - & - & - & - & - \\
\hline
\end{tabular}

I Stations $2 \mathrm{~A}$ and $8 \mathrm{~A}$ represent the 1963 collections

1 Stations $2 \mathrm{~A}$ and $8 \mathrm{~A}$ represent the
$2 \mathrm{~T}$ indicates less than $1 \%$ or $1 \mathrm{mg}$ 
TABLE 3.-The standing crops of benthos from different habitats in the Missouri River, Nebraska. Data for 1962 and 1963 are combined and expressed as pounds per acre

\begin{tabular}{|c|c|c|c|c|}
\hline \multirow[b]{2}{*}{ Habitat } & \multicolumn{2}{|c|}{ Unchannelized } & \multicolumn{2}{|c|}{ Channelized ${ }^{1}$} \\
\hline & Range & Average & Range & Average \\
\hline Main stream & $0.17-0.88$ & 0.43 & $0.02-0.20$ & 0.06 \\
\hline $\begin{array}{l}\text { Plle dike } \\
\text { Chute }\end{array}$ & $0.82-1.76$ & 1.36 & $\begin{array}{l}0.13-1 \\
0.38-15.65\end{array}$ & $\begin{array}{l}0.53 \\
7.28\end{array}$ \\
\hline Mud bank & $0.99-3.12$ & 2.38 & $0.47-23.91$ & 7.17 \\
\hline
\end{tabular}

1 Includes partially and completely channelized portion of the study area.

percentage of the weight of the few benthic organisms which were collected.

Tendipedids did not exhibit a clear-cut longitudinal pattern of distribution. Apparently the midges were better adapted for survival in sandy bottoms than were other organisms because it was in these areas that they were relatively most abundant. Based on their numerical abundance, $0^{\prime}$ Connell and Campbell (1953) reported midges as best able to survive in sand and gravel substrate in the Black River of Missouri.

Nothing definite can be said about the distributional patterns of the remaining taxa since they were collected infrequently. The unusual abundance of the Pelecypoda at Station $5(54 \%)$ represented the weight of one clam.

A standing crop of benthos was estimated for each of the habitats in the unchannelized and channelized sections of the river (Table $3)$. In both sections of the river the largest standing crop of benthos occurred in mud banks and chutes. Although Berner (1951) did not sample chutes in the lower Missouri River, he found a large standing crop of benthos in the mud banks. Richardson (1921) reported the richest sections of the Illinois River to be those areas where the current was sluggish and bottom deposits deepest.

The average standing crop of the main stream benthos was greater in the unchannelized section of the river than it was in the channelized section. Average standing crops in the chutes and mud banks were greater in the channelized portion of the river than in the unchannelized portion. Although these differences in average standing crops between the habitats occurred during both
TABLE 4.-The percentage composition of each type of habitat in the unchannelized and channelized sections of the Missouri River, Nebraska

\begin{tabular}{lcc}
\hline Habitat & Unchannelized & Channelized $^{1}$ \\
\hline Main stream & 81.0 & 88.0 \\
Chute & 15.8 & 2.0 \\
Mud bank & 3.0 & 6.6 \\
Pile dike & -0.2 & 0.4 \\
Rock & 0.0 \\
\hline 1 Includes partially and completely channelized portions
\end{tabular}
of the study area.

years, the size of the average standing crop in the main stream of the unchannelized river was increased because the 1963 collections were made adjacent to a mud bank. Here, both mayflies and caddis flies (characteristic of mud banks) were collected in the main stream.

Large standing crops of benthos in the chutes and mud banks of the channelized river were probably related to the downstream increases in silt turbidity. Some of the silt undoubtedly settled to form stable silty bottoms that were better suited for habitation by organisms than was the shifting substratum of the sandy chutes and mud banks farther upstream. Oligochaetes exhibited the greatest response to the habitable mud bottoms and they became increasingly prominent at Stations 7 to 9 .

Perhaps the most important information gained from the benthic study was a comparison of the size of standing crops in the unchannelized and channelized river. This depended upon weighting the estimated average standing crop of benthos in each habitat (Table 3) by the relative amount of that habitat in each section of the river and then summing these weights for the unchannelized and channelized river. Randomly established line transects were the basis for determining the amount of each type of habitat in each section of the river (Table 4).

Chutes showed the greatest reduction in percentage of total area between the two sections of the river; they were practically eliminated from the channelized river. Conversely, the estimated percentage of mud bank habitat doubled in the channelized portion. This increase, however, was not so much a result of channelization but rather a reflection of increased turbidity and deposition 
TABle 5.-The relative abundance of drift in the Missouri River, Nebraska. Values are expressed as percentage composition of the total wet weight for indicated habitats. Wet weights ( $m g$ ) are in parentheses

\begin{tabular}{|c|c|c|c|c|}
\hline \multirow{2}{*}{$\begin{array}{l}\text { Taxonomic } \\
\text { group }\end{array}$} & \multicolumn{2}{|c|}{ Unchannelized } & \multicolumn{2}{|c|}{ Channelized } \\
\hline & Main stream & Chute & Main stream & Pile dike \\
\hline Crustacea $^{1}$ & $88(8,234)$ & $87(51,175)$ & $49(2,202)$ & $3(89)$ \\
\hline $\begin{array}{l}\text { Cladocera } \\
\text { Daphnidae } \\
\text { Leptodoridae } \\
\quad \text { Leptodora kindti }\end{array}$ & $\begin{array}{r}100(8,200) \\
9(738) \\
91(7,462) \\
91(7,462)\end{array}$ & $\begin{array}{l}97(49,465) \\
10(5,164) \\
87(44,301) \\
87(44,301)\end{array}$ & $\begin{array}{l}93(2,051) \\
87(1,920) \\
6(131) \\
6(131)\end{array}$ & $\begin{array}{l}97(86) \\
20(18) \\
76(68) \\
76(68)\end{array}$ \\
\hline Eucopepoda & $\mathrm{T}^{2}(34)$ & $3(1,710)$ & $7(151)$ & $3(3)$ \\
\hline Insecta 1 & $11(1,042)$ & $1(341)$ & $45(2,001)$ & $97(3,414)$ \\
\hline Terrestrial insects & $10(102)$ & $25(85)$ & $23(469)$ & $22(753)$ \\
\hline $\begin{array}{l}\text { Aquatic insects } \\
\text { Collembola }\end{array}$ & $65(672)$ & $\begin{array}{l}40(137) \\
\mathrm{T}(1)\end{array}$ & $60(1,200)$ & $74(2,515)$ \\
\hline $\begin{array}{c}\text { Ephemeroptera } \\
\text { Baetidae } \\
\text { Ameletus } \\
\text { Brachycercus }\end{array}$ & $\begin{array}{l}15(158) \\
14(152) \\
1(15) \\
\end{array}$ & $\begin{array}{l}6(22) \\
6(22) \\
4(15) \\
2(7)\end{array}$ & $\begin{array}{c}19(389) \\
8(158) \\
4(72) \\
-\end{array}$ & $\begin{array}{l}60(2,058) \\
2(79) \\
2(63) \\
\end{array}$ \\
\hline $\begin{array}{l}\text { Caenis } \\
\text { Isonychia }\end{array}$ & $\begin{array}{c}3(32) \\
10(105)\end{array}$ & 二 & $\begin{array}{l}3(59) \\
1(27)\end{array}$ & $\mathrm{T}(16)$ \\
\hline $\begin{array}{l}\text { Ephemeridae } \\
\text { Ephoron }\end{array}$ & 二 & 二 & $\begin{array}{l}8(156) \\
8(156)\end{array}$ & $\overline{58}(1,979)$ \\
\hline $\begin{array}{l}\text { Heptageniidae } \\
\text { Stenonema }\end{array}$ & $1(6)$ & 二 & $\begin{array}{l}8(150) \\
4(75)\end{array}$ & $38(1,979)$ \\
\hline $\begin{array}{l}\text { Stenonema } \\
\text { Odonata }\end{array}$ & $1(6)$ & 二 & $4(75)$ & $\overrightarrow{\mathrm{T}}(4)$ \\
\hline Coenagrionidae & - & 二 & E & $\mathrm{T}(4)$ \\
\hline $\begin{array}{l}\text { Hemiptera } \\
\text { Corixidae }\end{array}$ & 二 & 二 & $\mathbf{T}(7)$ & $2(57)$ \\
\hline Trichoptera & $33(339)$ & $23(77)$ & $16(318)$ & $8(257)$ \\
\hline $\begin{array}{l}\text { Psychomyiidae } \\
\text { Neureclipsis }\end{array}$ & $2(26)$ & $22(75)$ & $\mathbf{T}(9)$ & - \\
\hline Hydropsychidae & $30(313)$ & $\begin{array}{l}22(75) \\
1(2)\end{array}$ & $16(309)$ & $\overline{8}(257)$ \\
\hline Arctopsyche & $12(129)$ & $1(2)$ & $10(193)$ & $8(257)$ \\
\hline $\begin{array}{l}\text { Hydropsyche } \\
\text { Potamyia }\end{array}$ & $\underline{18(184)}$ & 二 & $\begin{array}{l}2(39) \\
4(76)\end{array}$ & 二 \\
\hline Coleoptera & - & - & $-\infty$ & $\mathrm{T}(9)$ \\
\hline Dytiscidae & $\overline{10}(175)$ & $\overrightarrow{11}(37)$ & & $\mathbf{T}(9)$ \\
\hline $\begin{array}{l}\text { Diptera } \\
\text { Psychodidae }\end{array}$ & $18(175)$ & $11(37)$ & $24(486)$ & $4(130)$ \\
\hline $\begin{array}{l}\text { Psychodidae } \\
\text { Cullicidae }\end{array}$ & $T_{1}(10)$ & $\frac{1}{5(3)}$ & $5(104)$ & $1(29)$ \\
\hline Simuliidae & $2(19)$ & 1 (18) & $\mathrm{T}(9)$ & $1(36)$ \\
\hline Tendipedidae & 13 (139) & $4(13)$ & $12(235)$ & $1(45)$ \\
\hline Unidentified & $1(7)$ & - & $6(121)$ & $1(20)$ \\
\hline Insect remains & $25(268)$ & $35(119)$ & $17(332)$ & $4(146)$ \\
\hline Osteichthyes & $1(72)$ & $12(7,450)$ & $6(252)$ & - \\
\hline
\end{tabular}

1 The percentages under Crustacea and Insecta are based on those groups equalling $100 \%$

$2 \mathrm{~T}$ Indicates less than $1 \%$

of silt at successively lower downstream stations. Increasingly greater amounts of silt also caused a change in the bottom composition of the mud banks since silt became the major inorganic bottom constituent in downstream stations.

Rock habitat in the unchannelized river consisted of exposed bedrock while in the channelized section this habitat was composed entirely of rocks and boulders placed along stabilization structures. In neither case, however, did rocky bottoms harbor a typically benthic fauna. Organisms associated with the rocky bottoms crawled upon the rock surfaces, and for this reason the rock inhabitants were considered to be part of the aufwuchs community as described by Rutt- ner (1963), and were excluded from the benthos.

The average standing crop of benthos in the Missouri River before alteration by man is unknown. During this study the standing crop of benthos in the unchannelized river was estimated at 0.63 pounds per acre and 0.67 pounds per acre for the channelized river. These values are one and one-half times the 0.4 pound per acre average for the lower Missouri River (Berner, 1951). The average standing crop was small in both sections and negligible when compared to the average of 261 pounds per acre for much of the Illinois River (Richardson, 1921). A scarcity of benthos in the Missouri River was not surprising, however, since it possessed many of 
the characteristics that others have associated with low production of benthos. As reviewed by Berner (1951) these were: shifting substrate, siltation, fluctuating water level, swift current, and the absence of aquatic vegetation.

Line transects revealed the average width of the unchannelized river to be 2,363 feet and the average width of the channelized river to be 789 feet. Therefore, channelization reduced the surface area, and consequently the benthic habitat, by approximately $67 \%$. Much of this reduction in benthic area was accomplished by eliminating the comparatively productive chutes and associated slack water areas.

Drift.-Drift (as defined by Berner, 1951) was collected from Stations $2 \mathrm{~A}$ and $8 \mathrm{~A}$ during 1963.

Drifting organisms comprised only $2 \%$ of the material collected by the drift net; the remainder was mostly plant material. However, abattoir wastes became important at the lower station (8A) where it was three times as abundant by weight as were the organisms.

Three major groups of organisms occurred in the drift (Table 5). Crustacea were most abundant in the collections from the unchannelized river and the Insecta were most abundant in the channelized section. The dominance of Crustacea in the drift in the unchannelized river was by a limnetic cladoceran, Leptodora kindti (Focke), which comprised $87 \%$ of the weight of all crustaceans. Cowell (1967) reported this species to be present in appreciable numbers in the discharges from Lewis and Clark Reservoir. In the channelized river $85 \%$ of the Crustacea were members of the family Daphnidae.

Insecta generally contributed more to the drift than did the fish fry except for a single large collection of fry in the chute of the unchannelized river (Station 2A). Appearance of fish fry in the drift was probably transitory since they were a part of the drift for only a short period of time after hatching. Of the total weight of insects which were collected approximately $20 \%$ were terrestrial forms.

The standing crop of drift was much larger in the unchannelized section of the river than it was in the channelized section. At the un. channelized station the average standing crop was $68.3 \mathrm{~g}$ per acre-foot while at the channelized station the average standing crop was only $8.0 \mathrm{~g}$ per acre-foot. Moreover, it was estimated that $1,158 \mathrm{lb}$ of organisms flowed past a fixed point at the unchannelized station in 24 hours while at the channelized station only $652 \mathrm{lb}$ of organisms passed a fixed point during the same time. Berner (195l) calculated that $450 \mathrm{lb}$ of drift flowed past a given point in the lower Missouri River in 24, hours.

A general similarity between the species composition of the drift and benthos has been reported by Berner (1951), Maciolok and Needham (1951), and Muller (1954); however, the results of the present investigation suggested little if any similarity. None of the crustaceans or fish fry which were found in the drift occurred in the benthic samples. In like manner, most of the insects which commonly occurred in the drift were types that do not burrow, but are found on brush piles or similar substrates and are best considered as aufwuchs. For example, of the Ephemeroptera, members of the crawling and sprawling families Baetidae and Heptageniidae (Pennak, 1953), though common in the drift, were rarely taken in the benthos which was dominated by burrowing Ephemeridians. In like manner, the Trichoptera, primarily Hydropsychidae, though abundant in drift samples were relatively uncommon in the benthos. Oligochaetes also reflected the dissimilarity between drift and benthos as they occurred commonly in the benthos but were never recorded in the drift.

The only apparent similarity of species composition between drift and benthos occurred in the family Tendipedidae. This similarity, however, may be misleading as midges were identified only to family and those which occurred in the drift may not have occupied the same habitats as those in the benthos.

Because a large percentage of the drift was composed of aufwuchs, it appears that drift may be a better index to the relative availability of organisms as food for fishes 
than was the benthos. If aufwuchs was readily subjected to removal from the substrate by the current, these organisms could have been more easily preyed upon by fishes than the benthic organisms which are not as easily displaced by the current. For example, oligochaetes, which are burrowers, were frequently found in the benthos but never in the drift. Thus it is proposed that oligochaetes would not appear in the diet of fishes as frequently as would members of the Ephemeroptera families Baetidae and Heptageniidae or the Trichoptera family Hydropsychidae all of which were abundant in the drift. There are other interrelating factors such as electivity and predilection (Ivlev, 1961), but our hypothesis was generally substantiated by a study of the food habits of the flathead catfish and channel catfish (Langemeier, 1965; Russell, 1965).

\section{ACKNOWLEDGMENTS}

We thank Mr. Richard A. Kimerle, Department of Entomology, Oregon State University, Corvallis 97331, for assistance in the field investigations and in the identification of the invertebrates. We also thank personnel of the Nebraska Department of Health, Lincoln 68509, for water analysis.

\section{LITERATURE CITED}

Berner, L. M. 1951. Limnology of the lower Missouri River. Ecology 32(1) : 1-12.

Cowell, Bruce C. 1967. The Copepoda and Cladocera of a Missouri River reservoir: a comparison of sampling in the reservoir and the discharge. Limnol. and Oceanogr. 12(1): 125136.
ElLIS, M. M. 1937. Detection and measurement of stream pollution. Bull. 22, U. S. Bur. Fish. 48: $365-437$.

Geological Survey. 1963-1965. Surface water records of Nebraska. U. S. Dept. Int. Geol. Surv., Water Res. Div., Lincoln, Nebraska.

IvLEv, V. S. 1961. Experimental ecology of the feeding of fishes. Yale Univ. Press, Inc., New Haven. $302 \mathrm{p}$.

LANGEMEIER, R. N. 1965. Effects of channelization on the limnology of the Missouri River, Nebraska, with emphasis on food habits and growth of the flathead catfish. M.A. Thesis. Univ. of Missouri, Columbia. 156 p.

Leonard, J. W. 1939. Comments on the adequacy of accepted stream bottom sampling technique. Trans. 4th N. A. Wildl. Conf. 288-295.

MacioloK, J. A. ANd P. R. NEEDHAM. 1951. Ecological effects of winter conditions on trout and trout foods in Convict Creek, California. Trans. Amer. Fish. Soc. 81: 202-217.

Muller, K. 1954. Investigations on the organic drift in North Swedish streams. Inst. Freshwater Res., Drottningholm Sweden, Ann. Rept. 35: 133-148.

Neet, J. K., H. P. Nicholson, aNd A. Hirsch. 1963. Main stem reservoir effects on water quality in the Central Missouri River 1952-1957. U. S. Dep. Health, Educ. and Welfare, Pub. Health Serv., Region VI, Water Supply and Pollution Control, Kansas City, Missouri. 112 p.

O'Connell, T. R., JR., and R. S. Campbel. 1953. The benthos of Black River and Clearwater Lake, Missouri. Univ. of Missouri Stud. 26(2): $25-41$.

Pennak, R. W. 1953. Fresh-water invertebrates of the United States. The Ronald Press Co., New York. $769 \mathrm{p}$.

Richardson, R. E. 1921. The small bottom and shore fauna of the Middle and Lower Illinois River and its connecting lakes, Chillicothe to Grafton; its valuation; its sources of food supply; and its relation to the fishery. Illinois State Natural History Survey, Bull. 13: 363-522.

Russelt, T. R. 1965. Effects of channelization on the limnology of the Missouri River, Nebraska, with emphasis on food habits and growth of the channel catfish. M.A. Thesis. Univ. of Missouri, Columbia. $166 \mathrm{p}$.

RutTner, F. 1963. Fundamentals of limnology. University of Toronto Press. 295 p. 